\title{
Hubungan Testosteron dengan Motilitas Spermatozoa Tikus Putih Jantan (Ratus Norwegicus) Setelah Diberi Senyawa Aktif Daun Beluntas untuk Penyusun Buku Antifertilitas
}

\author{
Eko Susetyarini' ${ }^{1}$, Duran Corebima A², Moh. Amin², Trinil Susilawati ${ }^{3}$ \\ ${ }^{1}$ Pendidikan Biologi-Universitas Negeri Malang, \\ 2Jurusan Biologi-Universitas Negeri Malang \\ ${ }_{3}^{3}$ Fakultas Peternakan-Universitas Brawijaya
}

\section{INFO ARTIKEL}

Riwayat Artikel:

Diterima: 6 juni 2019

Disetujui: 2 Oktober 2019

\section{Kata kunci:}

Senyawa aktif

Kombinasi pemberian

Percobaan RAK

Motilitas Individu

\author{
Alamat Korespondensi: \\ Eko Susetyarini \\ Pendidikan Biologi \\ Universitas Negeri Malang \\ Jalan Semarang 5, Malang 65145 \\ E-mail: niniek08@gmail.com
}

\begin{abstract}
This research helps study the combination of active combination of beluntas leaf (tannin fraction; combined alkaloid + flavonoid + tannin fraction) with various doses of spermatogenic cell counts, spermatozoa quality, testosterone levels, damage to liver cells and black and white skin. This study is an experimental study, using RAK experimental design with a combination of types of active composition of beluntas leaves Based on the results of the study, it can be concluded that there is a combination of active combinations of beluntas leaves (tannin fraction; combined alkaloid + flavonoid + tannin) fractions with various benefits on the number of spermatogenic cells, individual motility, abnormalities, power live in male white rats; there is no combination for spermatozoa concentration and number of motile spermatozoa, and testosterone levels.
\end{abstract}

\begin{abstract}
Abstrak: Penelitian ini bertujuan untuk mengetahui pengaruh kombinasi pemberian jenis senyawa aktif daun beluntas (fraksi tanin; fraksi gabungan alkaloid+flavonoid+tanin) dengan berbagai dosis terhadap jumlah sel spermatogenik, kualitas spermatozoa, kadar testosteron, kerusakan sel hati dan ginjal tikus putih jantan, Penelitian ini merupakan penelitian eksperimen, menggunakan rancangan percobaan RAK dengan kombinasi perlakuan antara jenis senyawa aktif daun beluntas Berdasarkan hasil penelitian, dapat disimpulkan ada pengaruh kombinasi pemberian senyawa aktif daun beluntas (fraksi tanin; fraksi gabungan alkaloid+ flavonoid+tanin) dengan berbagai dosis terhadap jumlah sel spermatogenik, motilitas individu, abnormalitas, daya hidup pada tikus putih jantan; tidak ada pengaruh kombinasi untuk konsentrasi spermatozoa dan jumlah spermatozoa motil, dan kadar testosterone.
\end{abstract}

Penggunaan tanaman obat tradisional belum banyak digunakan sebagai obat antifertilitas oral pada pria. Salah satu tanaman tradisional yang termasuk kelompok obat antifertilitas, adalah beluntas (Pluchea indica). Beluntas biasa ditanam oleh masyarakat sebagai tanaman pagar, berkhasiat sebagai penghilang bau badan. Penelitian yang pernah dilakukan adalah merebus daun beluntas, air rebusan (dekok) tersebut diberikan ke tikus putih jantan yang berakibat pada spermatogenik, kadar testosteron, jumlah anakan tikus betina. Hasil penelitian yang dilakukan, yaitu pemberian dekok daun beluntas pada tikus putih jantan secara per oral. (E. 
Susetyarini, 2005), menyampaikan bahwa pemberian 0,5g dekok daun beluntas berpengaruh terhadap jumlah sel spermatogenik tikus putih jantan. Dekok dosis $0,5 \mathrm{~g}$ daun beluntas juga berpengaruh pada kadar testosteron tikus putih jantan (E. Susetyarini, 2003). Tikus putih jantan yang diberi dosis 0,5g dekok daun beluntas mempengaruhi jumlah anakan tikus putih betina setelah dikawinkan dengan tikus putih jantan (E. Susetyarini, 2004).

Penelitian tersebut di atas masih menggunakan rebusan daun beluntas. Dekok daun beluntas masih mengandung berbagai senyawa aktif dan belum diketahui jenis senyawa aktif yang berpengaruh pada antifertilitas tersebut. Pemberian senyawa aktif daun beluntas segar berupa ekstrak cair (R. E. Susetyarini, 2015) dan bubuk berpengaruh pada histologi testis tikus putih jantan (E. Susetyarini \& Wahyuni, 2008). Isolasi fraksi senyawa aktif pada daun beluntas kering berupa tanin, alkaloid dan flavonoid belum pernah dilakukan.

Senyawa aktif yang sangat penting pada tumbuhan, yaitu alkaloid, flavonoid, tanin dan komponen fenol (Edeoga, Okwu, \& Mbaebie, 2005). Kandungan senyawa aktif pada daun beluntas berupa tanin, alkaloid dan flavonoid (Dalimartha, 2008). Alkaloid merupakan senyawa bersifat basa yang mengandung satu atau lebih atom nitrogen, biasanya dalam gabungan sebagai bagian dari sistem siklik. Alkaloid mempunyai aktivitas fisiologi yang menonjol sehingga digunakan secara luas dalam pengobatan. Flavonoid merupakan salah satu golongan fenol. Flavonoid saat ini banyak mendapat perhatian karena mempunyai berbagai aktivitas farmakologis. Tanin senyawa aktif yang terkandung pada tumbuhan yang bersifat fenol, mempunyai rasa sepat (Harborne, 2005; Markham, 1988).

Fertilisasi adalah peleburan satu spermatozoa dengan sel telur, perkembangan berikut membentuk zigot, berkembang menjadi janin atau embrio sebagai suatu sosok kehidupan individu baru. Hewan coba jantan sebagai salah satu penentu keberhasilan keturunan sangat berperanan dalam mendukung program penelitian obat alami antifertilitas. Parameter antifertilitas yang diamati, adalah motilitas spermatozoa. Spermatozoa diambil dari cauda epididimis karena di dalam proses fertilisasi diperlukan konsnetrasi spermatozoa yang baik untuk dapat memfertilisasi sel telur. (Khaki et al., 2009; Salman \& Adesokan, 2008; Shittu et al., 2008). Proses maturasi di dalam epididimis spermatozoa mengalami perubahan struktural maupun fungsional (Orgebin-Crist, Danzo, \& Davies, 1975). Banyak komponen cairan epididimis yang berpengaruh selama maturasi, antara lain protein, karnitin, gliserilfosforilkolin, masitol, natrium, kalium, dan kalsium. Sekresi bahan-bahan tersebut oleh sel epitel epididimis sangat tergantung testosteron, khususnya 5dehidrotestosteron (Cornwall et al., 1986; Robaire \& Viger, 1995). Selama ini gerakan pengembangan pengobatan tradisional berbasis tumbuhan untuk antifertilitas pada pria belum banyak diungkap di masyarakat dan dibukukan. Hal tersebut sesuai pendapat seorang ahli Theophratus, beliau mengamati karakterisasi individu tanaman obat dan menulisnya dalam suatu buku. Materi yang dituliskan dalam buku sebaiknya berdasarkan dari bahan-bahan yang berakar di bumi Indonesia, yaitu hasil penelitian dari cendikiawan di Indonesia (Rifa'i, 2017)

Masyarakat akademisi belum banyak mengetahui tentang tanaman yang dapat digunakan sebagai obat antifertilitas. Gerakan penyebarluasan promosi alat kontrasepsi sering menggunakan strategi pendidikan, seperti pendidikan nonformal bagi masyarakat. Media yang strategis dan efektif digunakan untuk mengubah pola pikir masyarakat tentang antifertilitas disajikan dalam bentuk media cetak, yaitu buku obat antifertilitas alami. Buku bacaan ini disusun berdasarkan hasil penelitian yang telah dilakukan tentang antifertilitas dari daun beluntas. Hal ini sesuai dengan pernyataan (Rifa'i, 2017) yang menyatakan bahwa kebijakan DIKTI, yaitu hasil kegiatan kecendekiaan para pengajar perguruan tinggi di Indonesia dijuruskan untuk dimuarakan dalam bentuk penerbitan artikel ilmiah, pendaftaran hak paten dan penerbitan buku ilmiah. Penulisan buku, secara tegas dicanangkan harus berdasarkan pada hasil penelitian pengajar yang bersangkutan sehingga pembahasannya membumi pada persolaan yang ada di Indonesia. Buku ilmiah didefinisikan sebagai buku yang dipakai dalam mempelajari atau mendalami suatu subjek pengetahuan, ilmu, dan teknologi sehingga mengandung penyajian asas-asas tentang subjek tersebut, termasuk karya-karya ilmiah.

Penelitian ini bertujuan untuk memperoleh data tentang hubungan testosteron dengan motilitas spermatozoa individu spermatozoa tikus putih jantan setelah diberi jenis senyawa aktif daun beluntas dengan berbagai dosis serta untuk penyusunan buku antifertilitas alami. 


\section{METODE}

Jenis penelitian ini adalah eksperimen dengan rancangan percobaan RAK. Jenis senyawa aktif daun beluntas berupa bubuk, yaitu tanin dan gabungan flavonoid+alkaloid+tanin. Dosis yang digunakan, yaitu 4,7 $\mathrm{mg}$; 9,4 mg dan 14,1 $\mathrm{mg}$ dan kontrol (dosis $0 \mathrm{mg}$ ). Populasi yang digunakan tikus putih jantan (Ratus norwegicus) umur 2-3 bulan strain Wistar dengan berat badan rata-rata 150-175 g. Sampel yang diperlukan sebanyak 21 ekor tikus putih jantan untuk melihat kadar testosterone dan motilitas spermatozoa. Pengambilan sampel secara random.Tempat penelitian di laboratorium Biomedik FK UMM dan laboratorium SIMA. Kandang tikus ukuran panjang $45 \mathrm{~cm}$, lebar $35 \mathrm{~cm}$, tinggi $18 \mathrm{~cm}$, seperangkat tempat makan dan minum. Spuit disposable, seperangkat alat bedah, tabung plastik, mikroskop cahaya binoculer (Olymphus CH21) Japan, kamera digital Olymphus, appendorf. Bahan yang digunakan alkohol absolut, NaCl Fisiologis 0,9\%, TRIS. Variabel bebas dalam penelitian ini, adalah senyawa aktif daun beluntas (tanin dan gabungan tanin+alkaloid+flavonoid); variabel terikat, adalah kadar testosterone dan motilitas spermatozoa. Variabel yang dikendalikan oleh peneliti, adalah suhu, kandang, pakan, minum tikus putih, pencahayaan 12 jam pada waktu malam hari.

Cara kerja: sebelum diberi perlakuan, hewan coba diaklimatisasi selama 1 minggu dalam kondisi laboratorium. Perlakuan yang diberikan berupa bubuk tanin daun beluntas dan gabungan bubuk senyawa aktif daun beluntas yang diberikan secara oral pada tikus putih jantan dengan dosis 4,7 mg; 9,4 mg dan 14,1 mg dengan menggunakan sonde (Dalimartha, 2008); pemberian bubuk senyawa aktif tersebut dilakukan setiap hari sekali selama 7 hari pada tikus putih jantan; sedangkan kelompok kontrol diberi aquades secara oral setiap sehari sekali selama 7 hari. Selama percobaan pakan dan air minum PDAM diberikan secara ad libitum. Pakan yang diberikan adalah berupa pelet pakan (Br2).

Pengamatan kadar testosteron; pembedahan tikus dilakukan pada malam hari, karena masa kawin tikus putih jantan malam hari (Sodersten, Eneroth, \& Pettersson, 1983). Darah yang diambil menggunakan spuit dari aorta jantung kemudian darah disentrifuge. Darah yang telah disentrifuge diambil serumnya (Winarni, 2007), kemudian ditentukan kadar testosteron dengan teknik ELFA (Enzyme Linked Flourencent Assay). ELFA adalah suatu teknik deteksi dengan menggunakan metode serologis yang berdasarkan atas reaksi spesifik antara antigen dan antibodi, mempunyai sensitivitas dan spesifisitas yang tinggi dengan menggunakan enzim sebagai indikator.

Pemeriksaan motilitas spermatozoa: motilitas individu spermatozoa, semen yang sudah diencerkan diambil sekitar 10-15 $\mu$ dengan mikropipet kemudian diletakkan di atas obyek glass lalu ditutup dengan gelas penutup dan diamati menggunakan mikroskop cahaya dengan pembesaran 400 kali. Perhitungan dilakukan terhadap 100 ekor spermatozoa yang tampak pada lapangan pandang, spermatozoa dianggap motil jika bergerak aktif lurus ke depan, kemudian dihitung persentase spermatozoa yang motil (Rosida, 2007). Penilaian motilitas ditetapkan dengan skor 0, 1, 5, 3, 4, 5 (BIB Lembang, 1992). 0: spermatozoa imotif atau tidak bergerak; 1: gerakan berputar di tempat; 2: gerakan berayun atau melingkar, kurang dari 50 persen bergerak progeresif dan ada gelombang; 3: antara 50-80 persen spermatozoa bergerak progresif dan menghasilkan gerakan massa; 4: gerakan progresif yang gesit dan segera membentuk gelombang dengan 90 persen spermatozoa motif; 5: gerakan yang sangat progresif, gelombang yang sangat cepat, menunjukkan 100 persen spermatozoa motif aktif (Toelihere, 1993).

HASIL

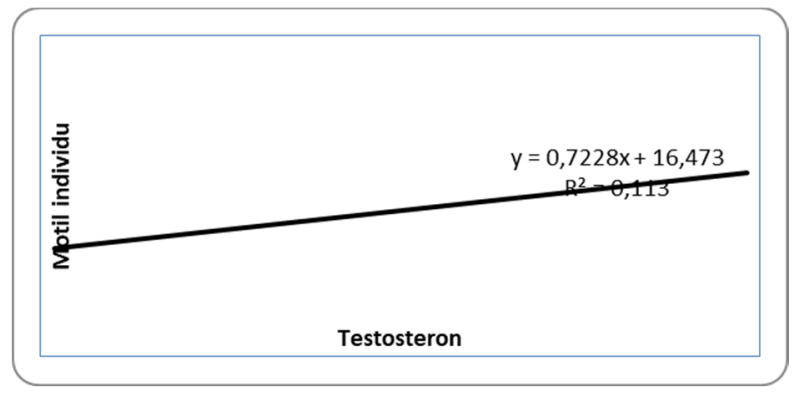

Gambar 1. Grafik Regresi antara Testosteron dengan Motilitas Individu Spermatozoa Tikus Putih Jantan setelah Diberi Senyawa Aktif Daun Beluntas 
Hasil analisis regresi antara testosteron dengan motilitas individu spermatozoa, disajikan pada Gbr 1. Pemberian perlakuan gabungan (alkaloid+flavonoid+tannin) dengan dosis 4,7 $\mathrm{mg}, 9,4 \mathrm{mg}$ dan $14,1 \mathrm{mg}$ menyebabkan kadar testosteron lebih tinggi dibanding pemberian senyawa aktif tannin dosis 4,7 mg; 9,4 mg dan dosis 14,1 mg. Perlakuan tannin dengan dosis 4,7 mg menyebabkan kadar testosteron rendah. Perlakuan tannin dengan dosis semakin tinggi menyebabkan kadar testosteron meningkat. Perlakuan gabungan (alkaloid+flavonoid+tannin) dosis $9,4 \mathrm{mg}$ menyebabkan kadar testosteron rendah dibanding pemberian senyawa aktif alkaloid+flavonoid+tannin dosis $4,7 \mathrm{mg}$ dan dosis 14,1 mg. Pemberian senyawa aktif gabungan (alkaloid+flavonoid+tannin) dosis $14,1 \mathrm{mg}$ menyebabkan kadar testosteron lebih tinggi dibanding pemberian senyawa aktif tannin+alkaloid+flavonoid dosis 4,7 $\mathrm{mg}$ dan dosis 9,4 mg. Kadar testosteron kelompok perlakuan (tannin dan gabungan) lebih rendah dibanding kelompok kontrol

Data motilitas individu spermatozoa tikus putih jantan pada kelompok kontrol (tanpa diberi perlakuan) menunjukkan persentase sebesar $43,33 \%$. Motilitas individu kelompok perlakuan pemberian senyawa aktif daun beluntas berupa tannin dengan dosis $4,7 \mathrm{mg}$ menunjukkan persentase sebesar 33,33\%. Motilitas individu kelompok perlakuan pemberian senyawa aktif daun beluntas berupa tannin dengan dosis $9,4 \mathrm{mg}$ menunjukkan persentase sebesar 26,67\%. Motilitas individu kelompok perlakuan pemberian senyawa aktif daun beluntas berupa tannin dengan dosis $14,1 \mathrm{mg}$ menunjukkan persentase sebesar 20,00\%. Motilitas individu kelompok perlakuan pemberian senyawa aktif daun beluntas berupa tannin+alkaloid+flavonoid dengan dosis 9,4 mg menunjukkan persentase sebesar 10,67\%. Motilitas individu kelompok perlakuan pemberian senyawa aktif daun beluntas berupa tannin+alkaloid+flavonoid dengan dosis 14,1 $\mathrm{mg}$ menunjukkan persentase sebesar $9,00 \%$. Motilitas individu kelompok perlakuan pemberian senyawa aktif daun beluntas berupa tannin+alkaloid+flavonoid dengan dosis 4,7 mg menunjukkan persentase sebesar 3,00\%. Penurunan kadar testosterone seiring dengan penurunan motilitas spermatozoa tikus putih jantan

Hasil analisis korelasi menunjukkan bahwa ada hubungan antara kadar testosteron dengan jumlah spermatozoa motil tikus putih jantan setelah diberi jenis senyawa aktif daun beluntas (tannin dan gabungan: alkaloid+flavonoid+tannin) dengan berbagai dosis (4,1 mg; 9,4 $\mathrm{mg}$ dan 14,1 $\mathrm{mg}$ ), dengan $\mathrm{r}$ square sebesar 0,195.Hasil analisis regresi antara kadar testosteron dengan motilitas individu spermatozoa tikus putih jantan setelah diberi jenis dan dosis senyawa aktif daun menunjukkan bahwa persamaan garis regresi $\mathrm{Y}=18,365+4,203 \mathrm{x}$. Hasil analisis regresi tersebut menunjukkan bahwa motilitas spermatozoa dipengaruhi kadar testosteron sebesar 19,5\%, dan 80,5\% dipengaruhi oleh faktor yang lain.

\section{PEMBAHASAN}

Motilitas spermatozoa dipengaruhi oleh hormon dan dipengaruhi oleh aktivitas metabolisme yang ada dalam spermatozoa. Testosteron berikatan dengan protein reseptor yang ada di epididimis. Protein reseptor melakukan tugas transduksi sinyal di dalam sel. Sinyal kimiawi terlebih dulu mengaktifkan reseptor, kemudian memicu suatu respon dalam sel target (Champbell, 2004). Diduga kadar testosteron pada tikus putih jantan dapat memacu respon pada spermatozoa yang ada di epididimis. Pematangan spermatozoa di epididimis dari spermatozoa non motil menjadi spermatozoa motil dipengaruhi oleh hormone testosteron serta faktor lain, yaitu enzim, nutrient yang disekresikan dari epitel epididimis. Zat-zat yang disekresikan, yaitu protein, karnitin, gliserilfosforilkolin, masitol, natrium, kalium, dan kalsium, Robaire dan Viger, dalam (Rosida, 2007). Zat-zat yang disekresikan dari epitrl epididimis berperanan dalam menjaga motilitas spermatozoa.

Flavonoid merupakan golongan senyawa estrogenik, mampu merangsang pembentukan estrogen, Cambine dan Brewis; Robinson, dalam (Ashfahani \& Wiratmini, 2010) yang akan meningkatkan kadar estrogen. Peningkatan kadar estrogen akan memberikan umpan balik negatif ke hipofisa anterior, yaitu FSH dan LH yang disekresikan sedikit. Penurunan kadar LH menyebabkan gangguan terhadap sekresi testosteron oleh sel leidig. Hormon testosteron berperanan dalam maturasi spermatozoa di epididymis, Robaire dan Herno, dalam (Ashfahani \& Wiratmini, 2010). Adanya gangguan terhadap sekresi testosteron maka kualitas spermatozoa yaitu motilitas individu spermatozoa terganggu.

Penciptaan arus informasi secara kontinyu, peran langsung masyarakat, pembinaan serta koordinasi/peran bersama yang dapat menumbuhkan kesadaran peran antar instansi maupun masyarakat secara koordinatif dan terintegrasi dapat dilakukan melalui penyampaian dan penyebarluasan hasil-hasil riset dan penelitian terapan yang dilakukan oleh instansi pemerintah, perguruan tinggi, industry maupun lembaga swadaya masyarakat dan hasilnya dapat dimanfaatkan langsung oleh masyarakat. Penyampaian dan penyebarluasan 
hasil riset atau penelitian tidak harus secara formal melalui sekolah, tetapi dapat melalui media masa yang diminati masyarakat, yaitu artikel dan bahan bacaan atau buku (Dahlia dalam Widowati, 2010).

Bahan bacaan memiliki keunggulan dibanding media lain, yaitu: 1) bahan bacaan relatif murah, biaya pemeliharaan relatif murah dan pemanfaatannya tidak memerlukan alat lain kecuali pencahayaan di malam hari, 2) bahan bacaan dapat dijangkau seluruh masyarakat khususnya yang sudah mampu membaca, 3) bahan bacaan merupakan sarana demokratisasi dan pemerataan ilmu pengetahuan dan teknologi, 4) ilmu pengetahuan dan informasi dalam bacaan dapat dibaca berkali-kali tanpa alat khusus untuk memantapkan pemahaman (Kartasasmita, 1995).

Naskah buku disusun dengan tampilan yang menarik, bahasa, visualisasi, isi yang mencakup konsepkonsep pembelajaran dalam bentuk kalimat yang motivasional, sehingga masyarakat tidak hanya mendapatkan informasi antifertilitas alami tetapi juga dapat merubah pola pikir masyarakat tentang penggunaan antifertilitas alami.

\section{SIMPULAN}

Ada hubungan antara kadar testosteron dengan motilitas individu spermatozoa tikus putih jantan setelah diberi jenis senyawa aktif daun beluntas (tannin dan gabungan: alkaloid+flavonoid+ tannin) dengan berbagai dosis (4,1 mg; 9,4 mg dan 14,1 mg), dengan r square sebesar 0,195. Motilitas spermatozoa dipengaruhi kadar testosteron sebesar $19,5 \%$, dan $80,5 \%$ dipengaruhi oleh faktor yang lain.

\section{DAFTAR PUSTAKA}

Ashfahani, E. D., \& Wiratmini, N. I. (2010). Motilitas Dan Viabilitas Spermatozoa Mencit (Mus musculus L.) Setelah Pemberian Ekstrak Temu Putih (Curcuma zedoaria (Berg.) Roscoe.). Jurnal Biologi Udayana, 14(1).

BIB Lembang. (1992). Prosedur dan Tatacara Kerja Distribusi Semen Beku. Direktorat Jenderal Peternakan Departemen Pertanian. BIB Lembang, Bandung.

Champbell, R. M. (2004). Biology. Jakarta: Erlangga.

Cornwall, G. A., Smyth, T. B., Vindivich, D., Harter, C., Robinson, J., \& Chang, T. S. K. (1986). Induction and enhancement of progressive motility in hamster caput epididymal spermatozoa. Biology of Reproduction, 35(4), 1065-1074.

Dalimartha, S. (2008). Atlas tumbuhan obat Indonesia (Vol. 2). Niaga Swadaya.

Edeoga, H. O., Okwu, D. E., \& Mbaebie, B. O. (2005). Phytochemical constituents of some Nigerian medicinal plants. African Journal of Biotechnology, 4(7), 685-688.

Harborne, I. B. (2005). Metode Fitokimia. Bandung: ITB.

Kartasasmita, G. (1995). Pemberdayaan Masyarakat: Sebuah Tinjauan Administrasi. Universitas Brawijaya.

Khaki, A., Fathiazad, F., Nouri, M., Khaki, A. A., Ozanci, C. C., Ghafari-Novin, M., \& Hamadeh, M. (2009). The effects of Ginger on spermatogenesis and sperm parameters of rat. Iranian Journal of Reproductive Medicine, 7(1).

Markham, K. R. (1988). Cara mengidentifikasi flavonoid. Bandung: ITB, 1-3.

Orgebin-Crist, M. C., Danzo, B. J., \& Davies, J. (1975). Endocrine control of the development and maintenance of sperm fertilizing ability in the epididymis.

Rifa'i, S. (2017). Media Pengajaran. Bandung: Sinar Baru Algensindo.

Robaire, B., \& Viger, R. S. (1995). Regulation of epididymal epithelial cell functions. Biology of Reproduction, 52(2), 226236.

Rosida, L. (2007). Pengaruh Pemberian Ekstrak Klroform Akar Pasak Bumi terhadap Motilitas dan Viabilitas Spermatozoa Mencit Jantan. Jurnal Obat Bahan Alam, 6(1), 20-26.

Salman, T. M., \& Adesokan, A. A. (2008). Sperm quality of male rats treated with aqueous extract of Enantia chlorantha stem bark. African Journal of Biotechnology, 7(7).

Shittu, L., Shittu, R., Adesite, S., Ajala, M. O., Bankole, M., Benebo, A. S., \& Ashiru, O. (2008). Fitoestrógenos Sesame radiatum Estimulan la Actividad Espermatogénica y Mejoran la Calidad del Esperma en el Testículo de Ratas Sprague Dawley Adulto de Sexo Masculino. International Journal of Morphology, 26(3), 643-652.

Sodersten, P., Eneroth, P., \& Pettersson, A. (1983). Episodic secretion of luteinizing hormone and androgen in male rats. Journal of Endocrinology, 97(1), 145-153.

Susetyarini, E. (2003). Kadar Testosteron Pada Tikus Putih Jantan (Ratus norwegicus) Yang Diberi Dekok Daun Beluntas. Laporan Penelitian.

Susetyarini, E. (2004). Jumlah Anakan Tikus Putih Betina (Ratus norwegicus) Yang Dikawinkan Dengan Tikus Putih Jantan (Ratus norwegicus) Yang Diberi Dekok Daun Beluntas.[Number of Females Puppies Rats (Rattus norvegicus) The Mated With Male Rats (Rattus norwegicus) Which leaves. Laporan Penelitian.

Susetyarini, E. (2005). Antispermatogenik Dekok Daun Beluntas Pada Tikus Putih jantan (Ratus norwegicus).[Antispermatogenik dekok Beluntas Leaves On White male rats (Rattus norvegicus)]. Laporan Penelitian. 
Susetyarini, E., \& Wahyuni, S. (2008). Pengembangan Senyawa Aktif Daun Beluntas Untuk Kontrasepsi per Oral Sebagai Upaya Pengembangan Bahan Anti fertilitas. Laporan Penelitian.

Susetyarini, R. E. (2015). Aktivitas tanin daun beluntas terhadap konsentrasi spermatozoa Tikus putih jantan. Jurnal Gamma, 8(2).

Toelihere, M. R. (1993). Fisiologi Reproduksi pada Ternak. penerbit Angkasa. Bandung.

Winarni, D. (2007). Efek ekstrak akar ginseng Jawa dan Korea terhadap libido mencit jantan pada prakondisi testosteron rendah. Berkala Penelitian Hayati, 12(2), 153-159. 